\title{
Toxicity of Volatile Methylated Species of Bismuth, Arsenic, Tin, and Mercury in Mammalian Cells In Vitro
}

\author{
E. Dopp, ${ }^{1}$ U. von Recklinghausen, ${ }^{1}$ J. Hippler, ${ }^{2}$ R. A. Diaz-Bone, ${ }^{2}$ J. Richard, ${ }^{1}$ \\ U. Zimmermann, ${ }^{1}$ A. W. Rettenmeier, ${ }^{1}$ and A. V. Hirner ${ }^{2}$ \\ ${ }^{1}$ Institute of Hygiene and Occupational Medicine, University of Duisburg-Essen, Hufelandstraße 55, 45122 Essen, Germany \\ ${ }^{2}$ Institute of Environmental Analytical Chemistry, University of Duisburg-Essen, Universitaetsstraße 3-5, 45141 Essen, Germany
}

Correspondence should be addressed to E. Dopp, elke.dopp@uni-due.de

Received 13 June 2011; Revised 8 August 2011; Accepted 8 August 2011

Academic Editor: Michael Aschner

Copyright (C) 2011 E. Dopp et al. This is an open access article distributed under the Creative Commons Attribution License, which permits unrestricted use, distribution, and reproduction in any medium, provided the original work is properly cited.

\begin{abstract}
The biochemical transformation of mercury, tin, arsenic and bismuth through formation of volatile alkylated species performs a fundamental role in determining the environmental processing of these elements. While the toxicity of inorganic forms of most of these compounds are well documented (e.g., arsenic, mercury) and some of them are of relatively low toxicity (e.g., tin, bismuth), the more lipid-soluble organometals can be highly toxic. In the present study we investigated the cyto- and genotoxicity of five volatile metal(loid) compounds: trimethylbismuth, dimethylarsenic iodide, trimethylarsine, tetramethyltin, and dimethylmercury. As far as we know, this is the first study investigating the toxicity of volatile metal(loid) compounds in vitro. Our results showed that dimethylmercury was most toxic to all three used cell lines ( $\mathrm{CHO}-9$ cells, $\mathrm{CaCo}$, Hep-G2) followed by dimethylarsenic iodide. Tetramethyltin was the least toxic compound; however, the toxicity was also dependend upon the cell type. Human colon cells ( $\mathrm{CaCo}$ ) were most susceptible to the toxicity of the volatile compounds compared to the other cell lines. We conclude from our study that volatile metal(loid) compounds can be toxic to mammalian cells already at very low concentrations but the toxicity depends upon the metal(loid) species and the exposed cell type.
\end{abstract}

\section{Introduction}

Biomethylation of metals and metalloids by microorganisms is a widespread phenomenon in anaerobic habitats including waste deposits, sewage sludge, and alluvial soils [1-3]. The stepwise methylation results in both partly methylated nonvolatile species as well as fully methylated volatile metal(loid) compounds. Considering the direct exposure to humans, the formation of volatile metal(loid) compounds by the intestinal biocenosis has attained considerable attention in the last years [4]. In vivo studies showed that after ingestion of bismuth subcitrate, the metal will be methylated by microbes in the gut and volatile trimethylbismuth $\left(\mathrm{Me}_{3} \mathrm{Bi}\right)$ can be detected in blood and breath [5]. Furthermore, arsenic, selenium, tellurium, and antimony were volatilized by the microbiocenosis of an in vitro model of the human intestinal microbiota [6]. Hollmann et al. have shown that colloidal bismuth subcitrate (CBS) as well as bismuth cysteine is methylated by human liver cells in vitro [7].
Whereas for the toxicity of nonvolatile methylated metal(loid) species, research has successively intensified in particular for arsenic [8-12] and mercury [13-15], little conclusive data are available in case of volatile species. The genotoxicity of volatile arsines has been a subject of several studies. Dimethylarsine $\left(\mathrm{Me}_{2} \mathrm{AsH}\right)$ induced DNA damage in human embryonic cells by formation of a peroxyl radical $\left(\mathrm{CH}_{3}\right)_{2} \mathrm{AsOO}_{*}[16]$. Furthermore, Kato et al. showed that trimethylarsine $\left(\mathrm{Me}_{3} \mathrm{As}\right)$ induced micronuclei in the bone marrow of mice after intraperitoneal injections of 8.5 and $14.7 \mathrm{mg} / \mathrm{kg}$ [17]. These findings were confirmed by Andrewes et al. [18] who investigated the DNA-damaging potential of $\mathrm{Me}_{2} \mathrm{AsH}$ and $\mathrm{Me}_{3} \mathrm{As}$ using supercoiled DNA. They concluded that the latter two arsines are about 100 times more potent than the most genotoxic nonvolatile arsenical, dimethylarsinous acid $\left(\mathrm{Me}_{2} \mathrm{AsOH}\right)$.

In comparison to nonvolatile species, volatile compounds demand a more complex experimental design and careful handling of the substances. Moreover, most studies focus on the toxicity of one compound or several compounds 
from one element, which makes a comparison between volatile organometal(loid) species difficult due to the different experimental systems used.

In this study, we aimed to comparatively investigate the cytotoxic and genotoxic effects of the volatile metal(loid) compounds trimethylbismuth $\left(\mathrm{Me}_{3} \mathrm{Bi}\right)$, dimethylarsenic iodide $\left(\mathrm{Me}_{2} \mathrm{AsI}\right)$, trimethylarsine $\left(\mathrm{Me}_{3} \mathrm{As}\right)$, tetramethyltin $\left(\mathrm{Me}_{4} \mathrm{Sn}\right)$, and dimethylmercury $\left(\mathrm{Me}_{2} \mathrm{Hg}\right)$.

For our studies, we developed an exposure system dedicated for the exposure to volatile organometal(loid) species. Three different cell types were chosen for toxicity testing: CHO-9 cells-an established cell system for toxicity testing, CaCo cells—human colon cells, and HepG2 cells-human hepatic cells. Same cell types were used in previous studies investigating cellular uptake and toxicity of nonvolatile organic and inorganic metal(loid) compounds [19-23]. To the best of our knowledge, this is the first study testing the toxicity of these volatile metal(loid) species in vitro.

\section{Material and Methods}

\subsection{Cell Cultures}

2.1.1. Human Hepatoma Cells. (HepG2) (ATCC, HB 8065) were cultured in minimal essential medium (MEM) with Earle's BSS and sodium bicarbonate (CC, PRO, Germany) supplemented with 10\% heat-inactivated FCS (Gibco), nonessential amino acids $(0.1 \mathrm{mM})$, sodium pyruvate (1 mM), and $100 \mathrm{IU} / \mathrm{mL}$ penicillin/streptomycin (CC, PRO).

2.1.2. Human Colon Cells. (CACO-2) (ATCC 169) were cultured in $75 \%$ MEM with 20\% FCS, 5\% nonessential amino acids $(0.1 \mathrm{mM}), 1 \%$ L-Glutamine, and $0.5 \%$ gentamycin.

2.1.3. Chinese Hamster Ovary Cells. (CHO) were purchased from ECACC (UK, Cat. no. 85050302) and grown in Ham's F12 medium (CC, PRO) supplemented with 10\% FCS, and $100 \mathrm{IU} / \mathrm{mL}$ penicillin/streptomycin (CC, PRO).

All the adherent growing cell lines were kept at $37^{\circ} \mathrm{C}$ in a $5 \% \mathrm{CO}_{2}$ atmosphere.

Prior to exposure approximately $2 \times 10^{6}$ cells were placed on the membrane of cell culture inserts (ThinCerts, $0.4 \mu \mathrm{m}$ membrane, transparent; Greiner bio-one, Germany) with $3 \mathrm{~mL}$ of their respective medium for $24 \mathrm{~h}$.

2.2. Reagents (Metal(loid) Compounds). All volatile organic metal(loid) compounds were of analytical grade unless stated otherwise and were either synthesized in the Institute of Environmental Analytical Chemistry or purchased from the following suppliers: trimethylbismuth $\left(\mathrm{Me}_{3} \mathrm{Bi}\right)$ from VeZerf (Idar-Oberstein, Germany), trimethylarsine $\left(\mathrm{Me}_{3} \mathrm{As}\right)$ from Sigma-Aldrich (Taufkirchen, Germany), tetramethyltin $\left(\mathrm{Me}_{4} \mathrm{Sn}\right)$ from Strem Chemicals (Kehl, Germany), and dimethylmercury ( $\mathrm{Me}_{2} \mathrm{Hg}$ ) from Acros Organics (Geel, Belgium). Dimethylarsine ( $\left.\mathrm{Me}_{2} \mathrm{AsI}\right)$ was synthesized as described in Styblo et al. [24]. Briefly, to $30 \mathrm{~mL}$ of an aqueous solution of dimethylarsenic acid $\left(\left(\mathrm{CH}_{3}\right)_{2} \mathrm{AsO}(\mathrm{OH})\right)$ and potassium iodide $(\mathrm{KI})$ concentrated sulphuric acid was

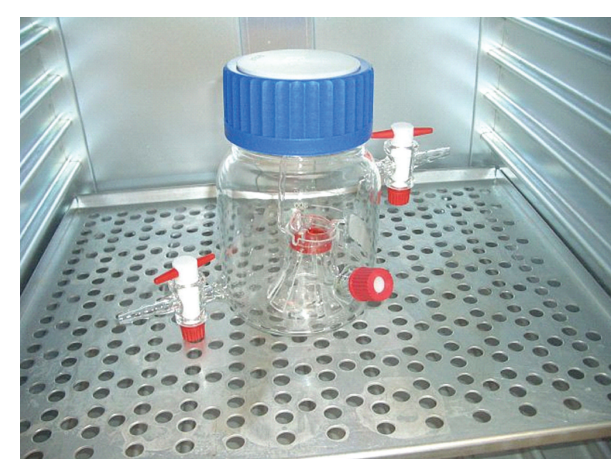

Figure 1: Modified glass flask for exposure of cells to volatile metal(loid) species. Cells were grown on permeable membranes. Exposure occurred through the membrane.

added. For the reduction step, $\mathrm{SO}_{2}$ was bubbled through the mixture and a yellow oil $\left(\left(\mathrm{CH}_{3}\right)_{2} \mathrm{AsI}\right)$ was separated after distillation. Identification was performed by ${ }^{1} \mathrm{H}-\mathrm{NMR}$ and GC-MS analysis (data not shown). Boiling points of all used metal(loid) species are given in Table 1 .

2.3. Exposure of Cells. For exposure of cells to the volatile organometal(loid) species, the ThinCert cell culture inserts were placed in $1000 \mathrm{~mL}$ glass flasks equipped with a Teflon screw cap and two plug valves in order to allow purging of the gas phase. Additionally, a septum screw cap for injection of the volatile test substances was fitted at the lower end of the glass flasks. To fix a ThinCert cell culture insert into the headspace of the exposure glass flask, a suitable glass rack was designed. During exposure, the flasks were stored in an incubator at $37^{\circ} \mathrm{C}$ (Figure 1). The culture medium was buffered with HEPES $(25 \mathrm{mM})$ (CCPro GmbH, Oberdorla, Germany).

Before exposure, the glass flask was closed and purged with argon for at least 3 minutes to purge oxygen out of the bottle because especially trimethylbismuth is extremely oxygen sensitive. Afterwards different amounts of one metal(loid) were injected through the septa screw cap and cells were exposed for $1 \mathrm{~h}$. This time point was chosen because of results from previous studies which showed that longer exposure times than $1 \mathrm{~h}$ caused a high degree of cytotoxicity (data not shown). Exposure concentrations were chosen according to the toxicity of the volatile species. Highly toxic species required lower concentrations than nontoxic species. The concentration range was evaluated in preexperiments (data not shown). After exposure, treated cells were harvested with trypsin $(0.05 \%)$ (Sigma) for the trypan blue test and the comet assay.

Control experiments with $\mathrm{Me}_{3}$ As verified that the cells are exposed through the membrane and not through the culture medium, as no cytotoxic effect was observable when a nonpermeable cover was placed below the membrane (data not shown).

2.4. Trypan Blue Test. To detect cytotoxicity in exposed cell cultures, cell viability was evaluated with the trypan blue 
TABLE 1: Boiling points of volatile metal(loid) species.

\begin{tabular}{lccc}
\hline Compound & Abbreviation & Boiling point & Reference \\
\hline Tetramethyltin & $\mathrm{Me}_{4} \mathrm{Sn}$ & $78^{\circ} \mathrm{C}$ & (Hoeppner et al., 1964) \\
Dimethylarsenic iodide & $\mathrm{Me}_{2} \mathrm{AsI}$ & $155-160^{\circ} \mathrm{C}$ & (Lee et al., 1923) \\
Trimethylarsine & $\mathrm{Me}_{3} \mathrm{As}$ & $51-53^{\circ} \mathrm{C}$ & (Dyke and Jones, 1930) \\
Trimethylbismuth & $\mathrm{Me}_{3} \mathrm{Bi}$ & $107.1^{\circ} \mathrm{C}$ & (Bamford et al., 1946) \\
Dimethylmercury & $\mathrm{Me}_{2} \mathrm{Hg}$ & $92^{\circ} \mathrm{C}$ & (Wilde, 1949) \\
\hline
\end{tabular}

test immediately after exposure of cells. The cell suspension was mixed with an equivalent volume of $0.4 \%$ trypan blue solution (Sigma) and subsequently evaluated under the light microscope. The membrane of dead cells is permeable to trypan blue (blue stained cells), whereas living cells remain unstained. Cell viability is expressed as percentage of surviving cells compared to the total number of cells:

$$
\% \text { viable cells }=\frac{\text { unstained cells }}{\text { unstained }+ \text { stained cells }} \times 100 .
$$

All experiments were repeated at least twice and significance was calculated by the Student's $t$-test. To compare the toxicity of the different metal(loid) compounds, $\mathrm{LC}_{50}$ values (lethal concentration to $50 \%$ of the cells) were calculated.

2.5. Alkaline Comet Assay. DNA damage was tested using the Alkaline Comet Assay, first described by Ostling and Johanson [25]. The Comet Assay is a sensitive microgel electrophoresis technique to detect DNA damage in single cells [25]. The assay was performed as described by Singh et al. [26] with minor modifications. In short, microgels were prepared by sticking a chamber slide (Chamber Slides LabTek II, Nalgene Nunc International, Rochester, USA) with eight chambers to a GelBond film (Lonza GmbH, Cologne, Germany). Each chamber was sealed by adding $50 \mu \mathrm{L}$ of $0.75 \%$ low melting point (LMP) agarose (Invitrogen $\mathrm{GmbH}$, Invitrogen $\mathrm{GmbH}$, Germany). $45 \mu \mathrm{L}$ of LMP agarose were mixed with $20 \mu \mathrm{L}$ cell suspension containing 8,000 cells. After solidification, cells were lysed overnight at $4^{\circ} \mathrm{C}$ in freshly prepared lysis solution. Prior to electrophoresis, the slides were incubated in electrophoresis solution for $20 \mathrm{~min}$. Electrophoresis was performed at $300 \mathrm{~mA}$ for $20 \mathrm{~min}$ and at $4^{\circ} \mathrm{C}$. Then the slides were kept in neutralisation solution for $30 \mathrm{~min}$ and further transferred to absolute ethanol for $2 \mathrm{~h}$ before the gels were left to dry overnight. The DNA was stained for $15 \mathrm{~min}$ using SYBR Green and the extent of DNA damage was analysed at a 40x magnification using the Comet Assay IV software (Perceptive Instruments, UK) and a CCD camera attached to a Leica Microscope. Statistical analysis was done using the Mann-Whitney test. The data of three individual experiments have been summarized and are plotted using their mean value and the standard error of mean.

\section{Results}

3.1. Cyto- and Genotoxicity of $\mathrm{Me}_{2} \mathrm{Hg}$. In comparison to the tested metal(oid) compounds, $\mathrm{Me}_{2} \mathrm{Hg}$ was the most
TABLE 2: $\mathrm{LC}_{50}$ values of the investigated volatile metal(loid) compounds in different cell lines (exposure time: $1 \mathrm{~h}$ ). Concentrations are given in $\mu \mathrm{mol} / L_{g v}$. n.ct.: not cytotoxic in the tested concentration range, n.t.: not tested.

\begin{tabular}{lccc}
\hline & CaCo & CHO-9 & HepG2 \\
\hline $\mathrm{Me}_{4} \mathrm{Sn}$ & 170.7 & n.ct. & n.ct. \\
$\mathrm{Me}_{2} \mathrm{AsI}$ & 334.5 & 11.2 & 10.8 \\
$\mathrm{Me}_{3} \mathrm{As}$ & 128.8 & 450 & 85.9 \\
$\mathrm{Me}_{3} \mathrm{Bi}$ & 110.0 & 128.0 & 194.0 \\
$\mathrm{Me}_{2} \mathrm{Hg}$ & 40.0 & 10.8 & n.t. \\
\hline
\end{tabular}

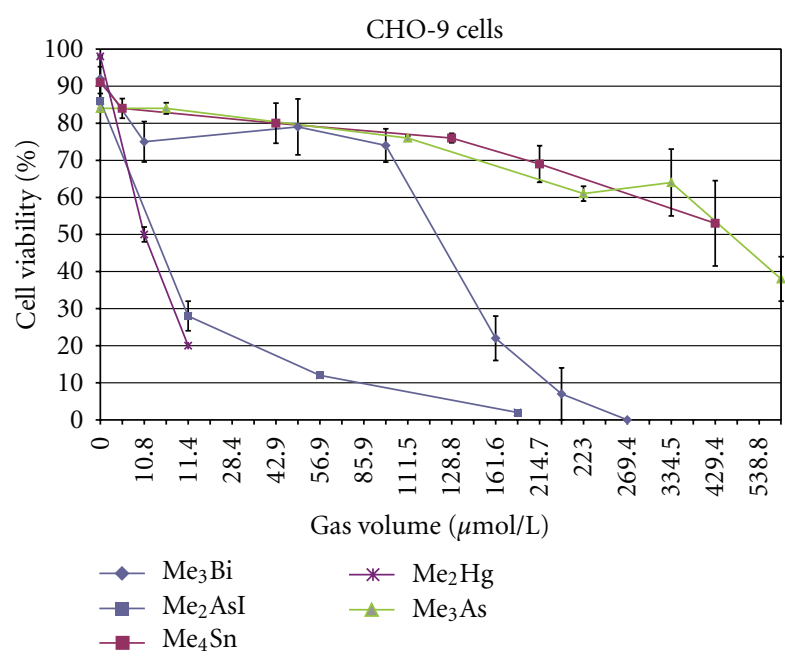

Figure 2: Comparison of cytotoxicity of 5 different metal(loid) compounds ( $\mathrm{Me}_{3} \mathrm{Bi}, \mathrm{Me}_{4} \mathrm{Sn}, \mathrm{Me}_{3} \mathrm{As}, \mathrm{Me}_{2} \mathrm{AsI}$, and $\mathrm{Me}_{2} \mathrm{Hg}$ ) in $\mathrm{CHO}-$ 9 cells. The experiments were repeated twice.

cytotoxic and induced $50 \%$ cell death $\left(\mathrm{LC}_{50}\right)$ in $\mathrm{CHO}-9$ cells already at the lowest concentration tested $\left(10.8 \mu \mathrm{mol} / \mathrm{L}_{\mathrm{gv}}\right)$ (Figure 2). The Comet Assay was not applicable in CHO-9 cells because the lowest tested concentration of $\mathrm{Me}_{2} \mathrm{Hg}$ was already cytotoxic to the cells. Due to the technical limitation of the minimal applicable droplet size, the applied concentration could not be reduced. Because of its extraordinary toxicity, not all cell lines were exposed to dimethyl mercury. Then, we abstained from exposure of the other cell lines to dimethyl mercury. The $\mathrm{LC}_{50}$ value for $\mathrm{Me}_{2} \mathrm{Hg}$ in CaCo cells was higher than in CHO-9 cells $\left(40 \mu \mathrm{mol} / \mathrm{L}_{\mathrm{gv}}\right)$, indicating a higher resistance of colon cells to the toxic compound than fibroblasts (Table 2). 


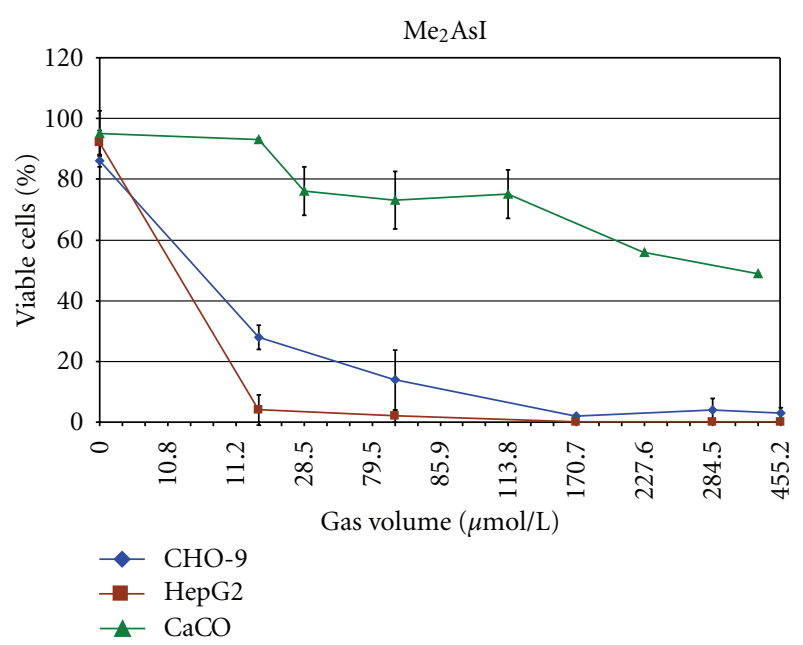

Figure 3: Cytotoxicity of $\mathrm{Me}_{2} \mathrm{AsI}$ in CHO-9, HepG2, and CaCo cells. The experiments were repeated three times.

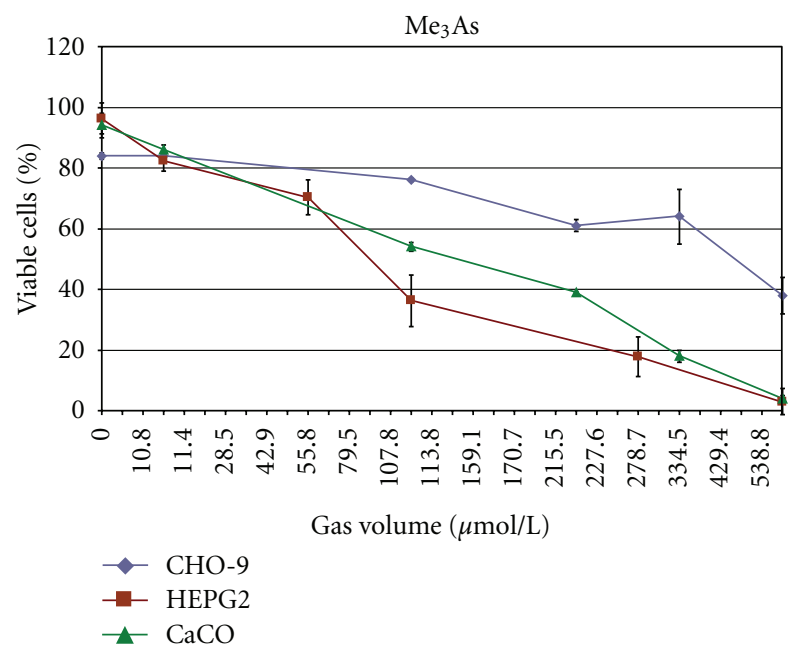

Figure 4: Cytotoxicity of $\mathrm{Me}_{3}$ As in CHO-9, HepG2, and CaCo cells. The experiments were repeated three times.

3.2. Cyto- and Genotoxicity of $M e_{2} A s I$ and $M e_{3} A s$. $\mathrm{Me}_{2} \mathrm{AsI}$ was highly cytotoxic in HepG2 cells $\left(\mathrm{LC}_{50}: 10.8 \mu \mathrm{mol} / \mathrm{L}_{\mathrm{gv}}\right)$ and $\mathrm{CHO}-9$ cells $\left(\mathrm{LC}_{50}: 11 \mu \mathrm{mol} / \mathrm{L}_{\mathrm{gv}}\right)$, whereas cytotoxicity in CaCo cells was considerably lower $\left(\mathrm{LC}_{50}: 335 \mu \mathrm{mol} / \mathrm{L}_{\mathrm{gv}}\right)$ (Figure 3, Table 2). Similar to $\mathrm{Me}_{2} \mathrm{Hg}$, testing of genotoxicity was not possible because of technical limitations in application of lower concentrations.

$\mathrm{Me}_{3} \mathrm{As}$ was cytotoxic in all three cell lines. HepG2 cells were most sensitive ( $\left.\mathrm{LC}_{50}: 86 \mu \mathrm{mol} / \mathrm{L}_{\mathrm{gv}}\right)$ followed by CaCo cells $\left(\mathrm{LC}_{50}: 129 \mu \mathrm{mol} / \mathrm{L}_{\mathrm{gv}}\right)$ and CHO-9 cells $\left(\mathrm{LC}_{50}\right.$ : $450 \mu \mathrm{mol} / \mathrm{L}_{\mathrm{gv}}$ ) (Figure 4 , Table 2 ). There were no significant genotoxic effects in CHO-9 cells detectable up to a concentration of $334 \mu \mathrm{mol} / \mathrm{L}_{\mathrm{gv}}$ (Figure 5). The highest tested concentration of $557 \mu \mathrm{mol} / \mathrm{L}_{\mathrm{gv}}$ induced significantly elevated tail moments in the comet assay, however, the cytotoxicity was reduced below $50 \%$ in these experiments.

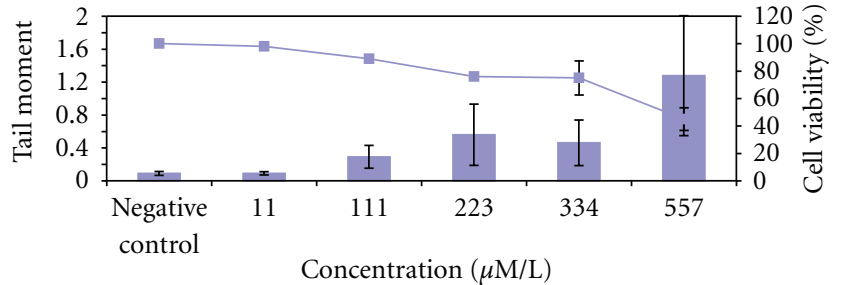

Tail moment $(\mathrm{CHO})$

Cell viability $(\mathrm{CHO})$

FIGURE 5: Genotoxicity of $\mathrm{Me}_{3} \mathrm{As}$ in $\mathrm{CHO}-9$ cells after $1 \mathrm{~h}$ exposure time measured by Comet-Assay. The tests were repeated three times.

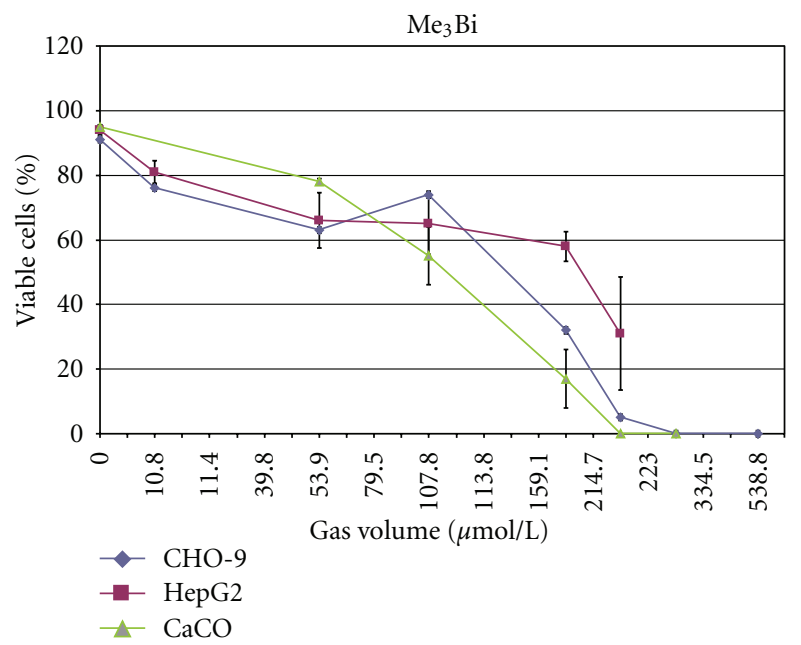

FIgure 6: Cytotoxicity of $\mathrm{Me}_{3} \mathrm{Bi}$ in $\mathrm{CHO}-9$, HepG2, and CaCo cells. The experiments were repeated three times.

3.3. Cyto- and Genotoxicity of $\mathrm{Me}_{3} B i$. The volatile $\mathrm{Me}_{3} \mathrm{Bi}$ was cytotoxic in all three tested cell lines (Figure 6).

$\mathrm{CaCo}$ cells were the most sensitive cell line ( $\mathrm{LC}_{50}: 110$ $\mu \mathrm{mol} / \mathrm{L}_{\mathrm{gv}}$ ), followed by CHO-9 cells ( $\left.\mathrm{LC}_{50}: 128 \mu \mathrm{mol} / \mathrm{L}_{\mathrm{gv}}\right)$ and HepG2 cells $\left(\mathrm{LC}_{50}\right.$ : $194 \mu \mathrm{mol} / \mathrm{L}_{\mathrm{gv}}$ ) (Table 2). Results of the Comet-Assay revealed that $\mathrm{Me}_{3} \mathrm{Bi}$ was genotoxic at concentrations $>108 \mu \mathrm{mol} / \mathrm{L}_{\mathrm{gv}}$ (Figure 7). However, at higher concentrations ( 162 and $216 \mu \mathrm{mol} / \mathrm{Lgv}_{\mathrm{gv}}$ ) $\mathrm{Me}_{3} \mathrm{Bi}$ was cytotoxic and thus genotoxic results were not evaluable anymore.

3.4. Cyto- and Genotoxicity of $\mathrm{Me}_{4} \mathrm{Sn} . \mathrm{Me}_{4} \mathrm{Sn}$ did not show a high level of cytotoxicity and induced $50 \%$ cell death $\left(\mathrm{LC}_{50}\right)$ just in CaCo cells at a concentration of $170.7 \mu \mathrm{mol} / \mathrm{L}_{\mathrm{gv}}$. In CHO-9 and HepG2 cells, the cell viability was not reduced below $50 \%$ up to a tested concentration of $429.4 \mu \mathrm{mol} / \mathrm{L}_{\mathrm{gv}}$ and $161.7 \mu \mathrm{mol} / \mathrm{Lgv}_{\mathrm{gv}}$, respectively (Figure 8 , Table 2 ).

Genotoxic effects in CHO-9 cells measured by Cometassay were not significantly elevated after $\mathrm{Me}_{4} \mathrm{Sn}$ exposure compared to the untreated control (Figure 9).

\section{Discussion}

From the metal(loid)s tested in this study, mercury is undoubtedly the most intensively investigated species, but 


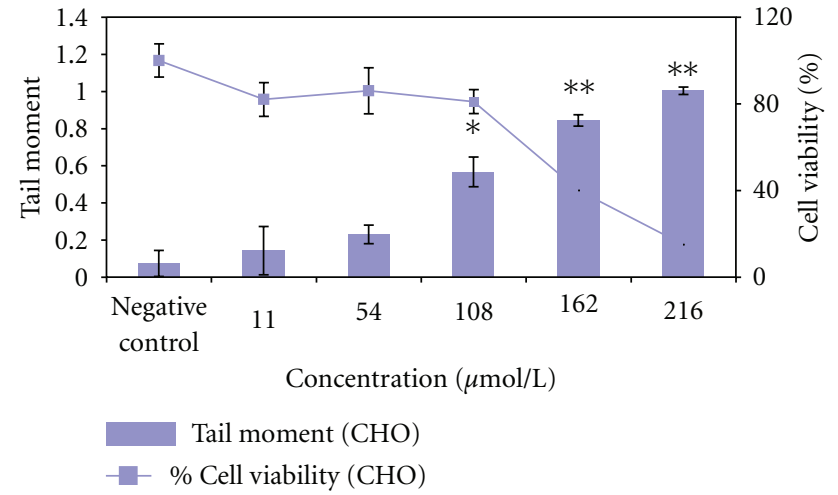

Figure 7: Genotoxicity of $\mathrm{Me}_{3} \mathrm{Bi}$ in $\mathrm{CHO}-9$ cells after 1 h exposure time measured by Comet-Assay. The tests were repeated three times. ${ }^{*} P \leq 0.05 ;{ }^{*} P \leq 0.01$.

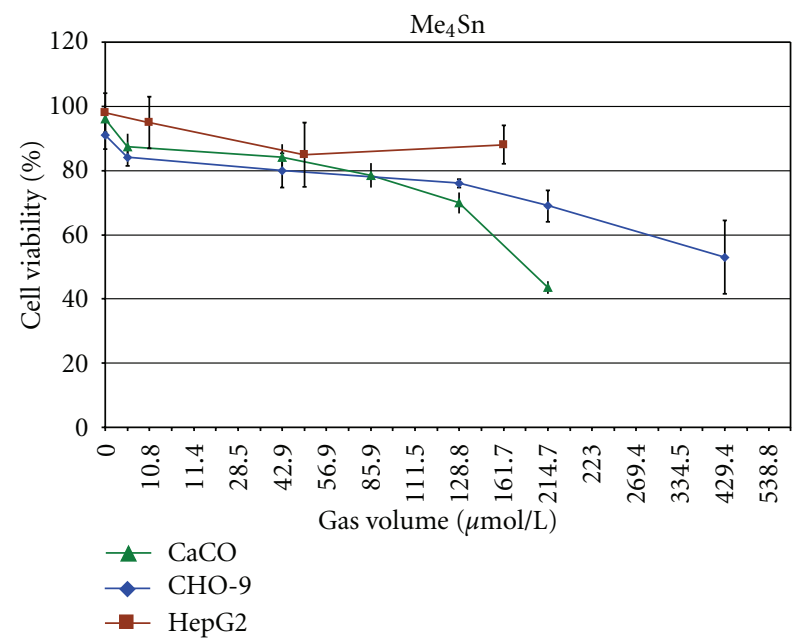

Figure 8: Cytotoxicity of $\mathrm{Me}_{4} \mathrm{Sn}$ in $\mathrm{CHO}-9$, HepG2, and CaCo cells. The experiments were repeated three times.

this applies only to elemental and monomethyl mercury but not to the dimethylated species. In our study, $\mathrm{Me}_{2} \mathrm{Hg}$ was highly cytotoxic in $\mathrm{CHO}-9$ and $\mathrm{CaCo}$ cells. Further studies regarding genotoxicity were not possible because of the high toxicity of $\mathrm{Me}_{2} \mathrm{Hg}$. The extraordinary toxicity of dimethylmercury is at least known since the death of Karen Wetterhahn in 1997, months after spilling no more than a few drops of this compound on her latex-gloved hand [27]. The reason for its extraordinary toxicity is the ability of this lipophilic compound to penetrate the cell membrane. Numerous studies have implicated a molecular mimicry in the uptake of thiol conjugates in selective target cells [28]. Ehrenstein et al. reported a negligible mercury concentration of mercury inside $\mathrm{CHO}$ cells after treatment with dimethylmercury [29]. The authors suggest from their study that the volatile mercury species escapes from the treatment solution before it can pass the cell membrane. In our experimental setup, the cells are directly and continuously exposed to the gaseous compound.

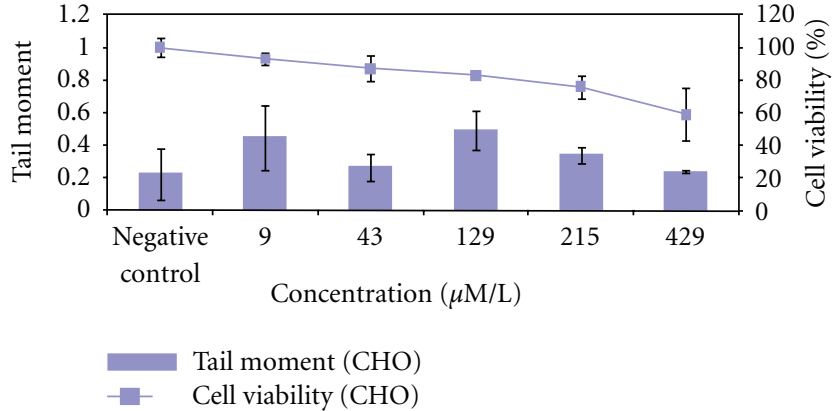

Figure 9: Genotoxicity of $\mathrm{Me}_{4} \mathrm{Sn}$ in CHO-9 cells after 1 h exposure time measured by Comet-Assay. The tests were repeated three times.

The toxicity of the volatile arsenic compounds $\mathrm{Me}_{2} \mathrm{AsI}$ and $\mathrm{Me}_{3} \mathrm{As}$ were studied in the present experiments. In both cell lines (CHO-9 and CaCo-2 cells), $\mathrm{Me}_{2}$ AsI exhibited a very high cytotoxicity similar to $\mathrm{Me}_{2} \mathrm{Hg}$. In comparison to nonvolatile $\mathrm{Me}_{2} \mathrm{AsOH}$, which is among the most toxic arsenic species reported [12], similar levels of toxicity were found when comparing the $\mathrm{LC}_{50}$-concentrations of gas (gv) and liquid (lv) volumes, respectively (Table 3 ). Furthermore, $\mathrm{Me}_{3} \mathrm{As}$ showed a significant cytotoxicity and genotoxic effects in contrast to the nonvolatile pentavalent form, $\mathrm{Me}_{3} \mathrm{AsO}$, which was not cytotoxic at the concentrations tested (Table 3).

Unexpectedly, we found significant differences between the different cell lines used. In particular, the cytotoxicity of $\mathrm{CaCo}$ cells towards $\mathrm{Me}_{2} \mathrm{AsI}\left(\mathrm{LC}_{50}: 335 \mu \mathrm{mol} / \mathrm{L}_{\mathrm{gv}}\right)$ was a factor of 30 lower than that found in CHO-9 and HepG2 cells. Contrary to $\mathrm{Me}_{2} \mathrm{AsI}, \mathrm{CHO}-9$ cells were a factor of 4 to 5 less susceptible to $\mathrm{Me}_{3} \mathrm{As}$ than $\mathrm{CaCo}$ and HepG2 cells, respectively. The low susceptibility of CaCo towards $\mathrm{Me}_{2} \mathrm{AsI}$ could be attributed to the ability of $\mathrm{CaCo}$ cell to express MRP2, a multidrug resistance protein capable of catalysing as efflux [30]. The different behaviours of $\mathrm{Me}_{2} \mathrm{AsI}$ and $\mathrm{Me}_{3} \mathrm{As}$ indicate different mechanisms of their toxicological action.

Methylated arsenic (III) species have been shown to be genotoxic in several test systems $[18,31-33]$ and are potent clastogens [34]. In the present experiments, we could not evaluate the genotoxicity of $\mathrm{Me}_{2} \mathrm{AsI}$ and $\mathrm{Me}_{3} \mathrm{As}$ because of its cytotoxicity at minimal applicable concentrations. $\mathrm{Me}_{3} \mathrm{As}$ showed significantly elevated tail moments only at cytotoxic concentrations, thus a genotoxicity testing was also not possible.

The nonvolatile bismuth species monomethylbismuth was already tested for cyto- and genotoxicity in human cells in an earlier study [23]. The results showed that the trivalent monomethylbismuth (MeBi(III)) exerted cytotoxicity even in micromolar concentrations in human hepatocytes $\left(\mathrm{LC}_{50}\right.$ : $350 \mu \mathrm{M})$ after $1 \mathrm{~h}$ exposure. In the present study, the cytotoxic effect of the volatile $\mathrm{Me}_{3} \mathrm{Bi}$ in $\mathrm{CaCo}, \mathrm{CHO}$, and HepG2 cells confirmed the observation that methylated bismuth compounds are more toxic than inorganic bismuth compounds. The $\mathrm{LC}_{50}$ value in $\mathrm{HepG} 2$ cells was $194 \mu \mathrm{mol} / \mathrm{L}_{\mathrm{gv}}$ for $\mathrm{Me}_{3} \mathrm{Bi}$ compared to $350 \mu \mathrm{mol} / \mathrm{L}_{\mathrm{lv}}$ for $\mathrm{MeBi}(\mathrm{III})$.

There seems to be a trend to an increased toxicity of methylated Bi compounds with augmented methyl groups 
TABLE 3: Comparison of toxicity of volatile to nonvolatile species (exposure time: 1 h; n.t.: not tested).

\begin{tabular}{|c|c|c|c|c|c|c|}
\hline Volatile compound & Cell type & $\mathrm{LC}_{50} \mu \mathrm{mol} / \mathrm{L}_{\mathrm{gv}}$ & Nonvolatile compound & Cell type & $\mathrm{LC}_{50} \mu \mathrm{mol} / \mathrm{L}_{\mathrm{lv}}$ & Literature \\
\hline $\mathrm{Me}_{4} \mathrm{Sn}$ & $\mathrm{CHO}$ & n.ct. (up to $400 \mu \mathrm{M}$ ) & $\mathrm{Me}_{3} \mathrm{SnCl}$ & $\mathrm{CHO}$ & n.ct. (up to $5 \mathrm{mM}$ ) & {$[20]$} \\
\hline $\mathrm{Me}_{2} \mathrm{AsI}$ & $\mathrm{CHO}$ & 11.2 & $\mathrm{Me}_{2} \mathrm{AsOH}$ & $\mathrm{CHO}$ & 10 & [19] \\
\hline $\mathrm{Me}_{2} \mathrm{AsI}$ & HepG2 & 10.8 & $\mathrm{Me}_{2} \mathrm{AsOH}$ & HepG2 & 18 & {$[22]$} \\
\hline $\mathrm{Me}_{3} \mathrm{As}$ & $\mathrm{CHO}$ & 450 & $\mathrm{Me}_{3} \mathrm{AsO}$ & $\mathrm{CHO}$ & n.ct. (up to $500 \mu \mathrm{M})$ & [19] \\
\hline $\mathrm{Me}_{3} \mathrm{As}$ & HepG2 & 85.9 & $\mathrm{Me}_{3} \mathrm{AsO}$ & HepG2 & n.ct. (up to $5000 \mu \mathrm{M}$ ) & {$[22]$} \\
\hline $\mathrm{Me}_{3} \mathrm{Bi}$ & HepG2 & 194 & MeBi(III) & HepG2 & 350 & {$[23]$} \\
\hline $\mathrm{Me}_{2} \mathrm{Hg}$ & $\mathrm{CHO}$ & 10.8 & $\mathrm{MeHgCl}$ & $\mathrm{CHO}$ & n.t. & \\
\hline
\end{tabular}

in HepG2 cells. Cytotoxicity of a trialkylated bismuth compound has been detected until now only with triphenylbismuth in human embryonic lung fibroblasts [35]. In the experiments of von Recklinghausen et al. [23] with $\mathrm{MeBi}(\mathrm{III})$, the authors demonstrated that the compound is able to induce genomic damage in human lymphocytes by induction of a significant number of chromosomal aberrations and sister chromatid exchanges after $24 \mathrm{~h}$ exposure time. In the present experiments, we also detected DNA damage after an exposure of CHO- 9 cells to $\mathrm{Me}_{3} \mathrm{Bi}$ for 1 hour only. Also here, $\mathrm{Me}_{3} \mathrm{Bi}$ seems to be more toxic than $\mathrm{MeBi}(\mathrm{III})$.

Recent studies with methylated tin compounds in vitro revealed a considerable toxicological potential of some organotin species but demonstrated clearly that the toxicity is modulated by the cellular uptake capability [20]. The highly hydrophobic and volatile compound $\mathrm{Me}_{4} \mathrm{Sn}$ induced neither cytotoxicity detected by using the trypan blue test nor genotoxicity evaluated with the comet assay in CHO-9 cells up to a tested concentration of $429 \mu \mathrm{mol} / \mathrm{L}_{\mathrm{gv}}$.

\section{Summary}

In summary, the present study indicates that some volatile organometal(loid) compounds are able to exhibit a significant toxicity to mammalian cells. While exposure to volatile organometal(loid)s in the environment is relatively rare, the formation of these compounds in the intestine may contribute to the toxicity of ingested metal(loid)s.

In accordance to methylated volatile arsenic species, recent studies of our group indicated that the induction of cyto- and genotoxic effects caused by the nonvolatile trivalent methylated arsenic species is primarily dependent upon their ability to penetrate the cell membrane [12]. Likewise, we assume that the high cyto- and genotoxicity for volatile organometal(loid) compounds found in this study can be attributed to their ability to pass cell membranes.

The observation that the toxicity highly depends both upon the metal(loid) species and the exposed cell type indicates different mechanisms of their toxicological action, which need to be subject of further studies.

\section{Abbreviations}

$\mathrm{Me}_{3} \mathrm{Bi}:$ Trimethylbismuth

$\mathrm{Me}_{2}$ AsI: Dimethylarsenic iodide

$\mathrm{Me}_{3}$ As: Trimethylarsine

$\mathrm{Me}_{4} \mathrm{Sn}$ : Tetramethyltin
$\mathrm{Me}_{2} \mathrm{Hg}$ : Dimethylmercury

gv: Gas volume

lv: Liquid volume

$\mathrm{LC}_{50}$ : Lethal concentration causing death of $50 \%$

of the cells

CaCo: Human colon cells

HepG2: Human hepatoma cells

CHO: Chinese hamster ovary cells

Me: Methyl group.

\section{Acknowledgments}

The authors thank Gabriele Zimmer and Melanie Gerhards for excellent technical assistance.

\section{References}

[1] J. Feldmann and A. V. Hirner, "Occurrence of volatile metal and metalloid species in landfill and sewage gases," International Journal of Environmental Analytical Chemistry, vol. 60, pp. 339-359, 1995.

[2] J. Meyer, A. Schmidt, K. Michalke, and R. Hensel, "Volatilisation of metals and metalloids by the microbial population of an alluvial soil," Systematic and Applied Microbiology, vol. 30, no. 3, pp. 229-238, 2007.

[3] K. Michalke, E. B. Wickenheiser, M. Mehring, A. V. Hirner, and R. Hensel, "Production of volatile derivatives of metal(loid)s by microflora involved in anaerobic digestion of sewage sludge," Applied and Environmental Microbiology, vol. 66, no. 7, pp. 2791-2796, 2000.

[4] R. A. Diaz-Bone and T. van de Wiele, "Biotransformation of metal(loid)s by intestinal microorganisms," Pure and Applied Chemistry, vol. 82, no. 2, pp. 409-427, 2010.

[5] J. Boertz, L. M. Hartmann, M. Sulkowski et al., "Determination of trimethylbismuth in the human body after ingestion of colloidal bismuth subcitrate," Drug Metabolism and Disposition, vol. 37, no. 2, pp. 352-358, 2009.

[6] R. A. Diaz-Bone and T. R. van de Wiele, "Biovolatilization of metal(loid)s by intestinal microorganisms in the simulator of the human intestinal microbial ecosystem," Environmental Science and Technology, vol. 43, no. 14, pp. 5249-5256, 2009.

[7] M. Hollmann, J. Boertz, E. Dopp, J. Hippler, and A. V. Hirner, "Parallel on-line detection of a methylbismuth species by hyphenated GC/EI-MS/ICP-MS technique as evidence for bismuth methylation by human hepatic cells," Metallomics, vol. 2, no. 1, pp. 52-56, 2010.

[8] A. Wang, S. D. Holladay, D. C. Wolf, S. A. Ahmed, and J. L. Robertson, "Reproductive and developmental toxicity 
of arsenic in rodents: a review," International Journal of Toxicology, vol. 25, no. 5, pp. 319-331, 2006.

[9] C. H. Tseng, "Arsenic methylation, urinary arsenic metabolites and human diseases: current perspective," Journal of Environmental Science and Health C, vol. 25, no. 1, pp. 1-22, 2007.

[10] U. Schuhmacherwolz, H. H. Dieter, D. Klein, and K. Schneider, "Oral exposure to inorganic arsenic: evaluation of its carcinogenic and non-carcinogenic effects," Critical Reviews in Toxicology, vol. 39, no. 4, pp. 271-298, 2009.

[11] E. Dopp, L. M. Hartmann, A. M. Florea, A. W. Rettenmeier, and A. V. Hirner, "Environmental distribution, analysis, and toxicity of organometal(loid) compounds," Critical Reviews in Toxicology, vol. 34, no. 3, pp. 301-333, 2004.

[12] E. Dopp, A. D. Kligerman, and R. A. Diaz-Bone, "Organoarsenicals. Uptake, metabolism, and toxicity," in Organometallics in Environment and Toxicology, A. Sigl, H. Sigl, and R. K. O. Sigl, Eds., vol. 7, The Royal Society of Chemistry, Cambridge, UK, 2010.

[13] G. J. Myers and P. W. Davidson, "Prenatal methylmercury exposure and children: neurologic, developmental, and behavioral research," Environmental Health Perspectives, vol. 106, supplement 3, pp. 841-847, 1998.

[14] T. W. Clarkson and J. J. Strain, "Nutritional factors may modify the toxic action of methyl mercury in fish-eating populations," Journal of Nutrition, vol. 133, no. 5, supplement 1, pp. 1539S-1543S, 2003.

[15] D. A. Geier, P. G. King, L. K. Sykes, and M. R. Geier, "A comprehensive review of mercury provoked autism," Indian Journal of Medical Research, vol. 128, no. 4, pp. 383-411, 2008.

[16] K. Yamanaka, M. Hoshino, M. Okamoto, R. Sawamura, A. Hasegawa, and S. Okada, "Induction of DNA damage by dimethylarsine, a metabolite of inorganic arsenics, is for the major part likely due to its peroxyl radical," Biochemical and Biophysical Research Communications, vol. 168, no. 1, pp. 5864, 1990.

[17] K. Kato, K. Yamanaka, A. Hasegawa, and S. Okada, "Active arsenic species produced by GSH-dependent reduction of dimethylarsinic acid cause micronuclei formation in peripheral reticulocytes of mice," Mutation Research-Genetic Toxicology and Environmental Mutagenesis, vol. 539, no. 1-2, pp. 55-63, 2003.

[18] P. Andrewes, K. T. Kitchin, and K. Wallace, "Dimethylarsine and trimethylarsine are potent genotoxins in vitro," Chemical Research in Toxicology, vol. 16, no. 8, pp. 994-1003, 2003.

[19] E. Dopp, L. M. Hartmann, A. M. Florea et al., "Uptake of inorganic and organic derivatives of arsenic associated with induced cytotoxic and genotoxic effects in Chinese hamster ovary (CHO) cells," Toxicology and Applied Pharmacology, vol. 201, no. 2, pp. 156-165, 2004.

[20] E. Dopp, L. M. Hartmann, U. von Recklinghausen et al., "The cyto- and genotoxicity of organotin compounds is dependent on the cellular uptake capability," Toxicology, vol. 232, no. 3, pp. 226-234, 2007.

[21] E. Dopp, L. M. Hartmann, U. von Recklinghausen et al., "Forced uptake of trivalent and pentavalent methylated and inorganic arsenic and its cyto-/genotoxicity in fibroblasts and hepatoma cells," Toxicological Sciences, vol. 87, no. 1, pp. 4656, 2005.

[22] E. Dopp, U. Von Recklinghausen, L. M. Hartmann et al., "Subcellular distribution of inorganic and methylated arsenic compounds in human urothelial cells and human hepatocytes," Drug Metabolism and Disposition, vol. 36, no. 5, pp. 971-979, 2008.
[23] U. von Recklinghausen, L. M. Hartmann, S. Rabieh et al., "Methylated bismuth, but not bismuth citrate or bismuth glutathione, induces cyto- and genotoxic effects in human cells in vitro," Chemical Research in Toxicology, vol. 21, no. 6, pp. 1219-1228, 2008.

[24] M. Styblo, S. V. Serves, W. R. Cullen, and D. J. Thomas, "Comparative inhibition of yeast glutathione reductase by arsenicals and arsenothiols," Chemical Research in Toxicology, vol. 10, pp. 27-33, 1997.

[25] O. Ostling and K. J. Johanson, "Microelectrophoretic study of radiation-induced DNA damages in individual mammalian cells," Biochemical and Biophysical Research Communications, vol. 123, no. 1, pp. 291-298, 1984.

[26] N. P. Singh, M. T. McCoy, R. R. Tice, and E. L. Schneider, "A simple technique for quantitation of low levels of DNA damage in individual cells," Experimental Cell Research, vol. 175, no. 1, pp. 184-191, 1988.

[27] P. Gwynne, "Researchers' deaths inspire actions to improve safety," The Scientist, vol. 11, p. 21, 1997.

[28] C. C. Bridges and R. K. Zalups, "Molecular and ionic mimicry and the transport of toxic metals," Toxicology and Applied Pharmacology, vol. 204, no. 3, pp. 274-308, 2005.

[29] C. Ehrenstein, P. Shu, E. B. Wickenheiser et al., "Methyl mercury uptake and associations with the induction of chromosomal aberrations in Chinese hamster ovary (CHO) cells," Chemico-Biological Interactions, vol. 141, no. 3, pp. 259274, 2002.

[30] Z. Drobná, F. S. Walton, D. S. Paul, W. Xing, D. J. Thomas, and M. Stýblo, "Metabolism of arsenic in human liver: the role of membrane transporters," Archives of Toxicology, vol. 84, no. 1, pp. 3-16, 2010.

[31] M. J. Mass, A. Tennant, B. C. Roop et al., "Methylated trivalent arsenic species are genotoxic," Chemical Research in Toxicology, vol. 14, no. 4, pp. 355-361, 2001.

[32] S. Ahmad, K. T. Kitchin, and W. R. Cullen, "Plasmid DNA damage caused by methylated arsenicals, ascorbic acid and human liver ferritin," Toxicology Letters, vol. 133, no. 1, pp. 4757, 2002.

[33] S. Nesnow, B. C. Roop, G. Lambert et al., "DNA damage induced by methylated trivalent arsenicals is mediated by reactive oxygen species," Chemical Research in Toxicology, vol. 15, no. 12, pp. 1627-1634, 2002.

[34] A. D. Kligerman, C. L. Doerr, A. H. Tennant et al., "Methylated trivalent arsenicals as candidate ultimate genotoxic forms of arsenic: induction of chromosomal mutations but not gene mutations," Environmental and Molecular Mutagenesis, vol. 42, no. 3, pp. 192-205, 2003.

[35] H. R. Rawls, M. V. Marshall, H. L. Cardenas, H. R. Bhagat, and I. Cabasso, "Cytotoxicity evaluation of a new radiopaque resin additive-triphenyl bismuth," Dental Materials, vol. 8, no. 1, pp. 54-59, 1992. 

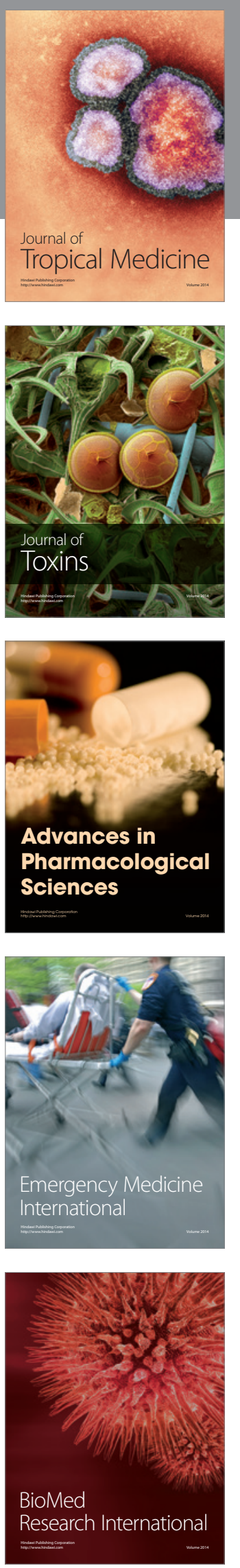
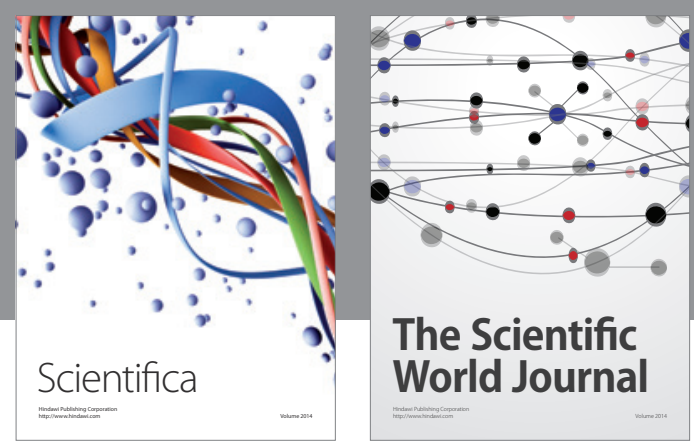

The Scientific World Journal
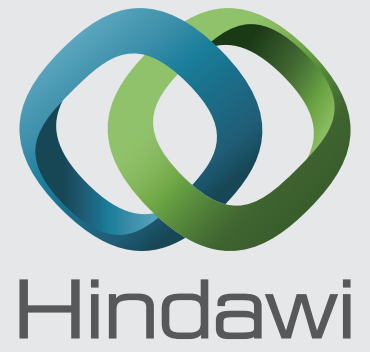

Submit your manuscripts at

http://www.hindawi.com
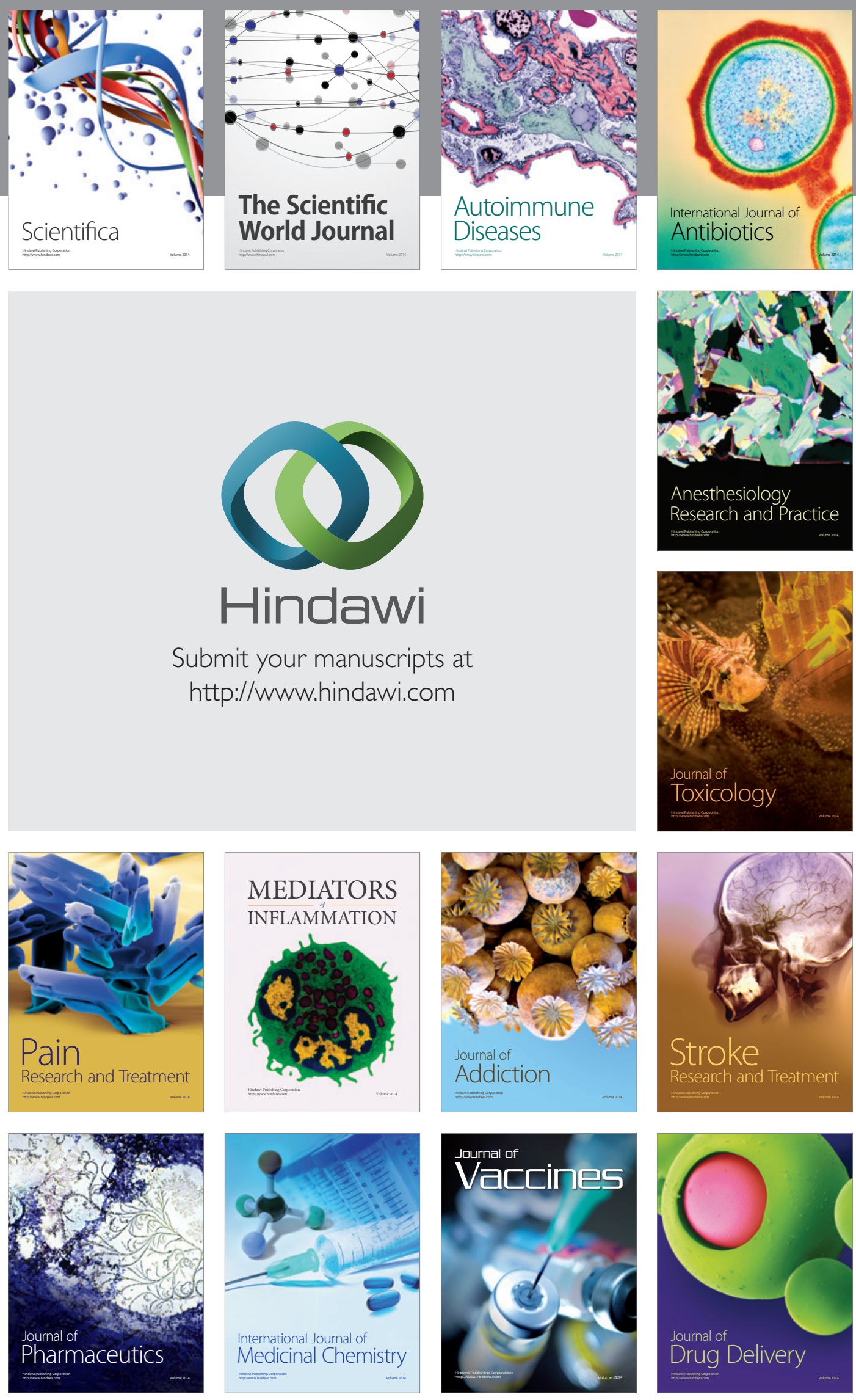